\title{
Sea Lamprey Petromyzon marinus Biology and Management Across Their Native and Invasive Ranges: Promoting Conservation by Knowledge Transfer
}

Z. Guo, D. Andreou, and J. R. Britton

\section{QUERY SHEET}

This page lists questions we have about your paper. The numbers displayed at left can be found in the text of the paper for reference. In addition, please review your paper as a whole for correctness.

Q1. Au: Please confirm author names and affiliations are correct.

Q2. Au: Please confirm correspondence information is correct and complete.

Q3. Au: Reference "Kuratani et al., 2002" is not included in the reference list. Please provide full reference information or remove citation.

Q4. Au: Reference "Laine et al., 1998" is not included in the reference list. Please provide full reference information or remove citation.

Q5. Au: Please confirm whether or not you need permission to reproduce tables 2 and 3. If you need permissions, please confirm you've obtained them and please provide the rightsholder for each. The rightsholder is most often the publisher and information about obtaining permissions is listed on their website.

Q6. Au: Reference "Sorensen and Stacey, 2004" is not included in the reference list. Please provide full reference information or remove citation.

Q7. Au: Please provide volume number and page range for reference "Hansen et al., 2016".

Q8. Au: Please provide volume number and page range for reference "Pinder et al., 2015".

\section{TABLE OF CONTENTS LISTING}

The table of contents for the journal will list your paper exactly as it appears below:

Sea Lamprey Petromyzon marinus Biology and Management Across Their Native and Invasive Ranges: Promoting Conservation by Knowledge Transfer

Z. Guo, D. Andreou, and J. R. Britton 


\title{
Sea Lamprey Petromyzon marinus Biology and Management Across Their Native and Invasive Ranges: Promoting Conservation by Knowledge Transfer
}

\author{
Z. Guo ${ }^{\mathrm{a}, \mathrm{b}}$, D. Andreou ${ }^{\mathrm{b}}$, and J. R. Britton ${ }^{\mathrm{b}}$
}

${ }^{a}$ Key Laboratory of Tropical Marine Bio-resources and Ecology, Guangdong Provincial Key Laboratory of Applied Marine Biology, South China

5 Sea Institute of Oceanology, Chinese Academy of Sciences, Guangzhou, China; ${ }^{b}$ Centre for Conservation Ecology and Environmental Sciences, Faculty of Science and Technology, Bournemouth University, Poole, Dorset, UK

\section{ABSTRACT}

The anadromous sea lamprey Petromyzon marinus native range extends across the Northern Atlantic and includes much of Europe. Their complex lifecycle, involving freshwater spawning, juveniles (ammocoetes) that remain in freshwater for up to eight years, and adults migrating to sea before returning to reproduce, means native populations in Europe are threatened by multiple stressors, especially migration blockages and habitat loss. This has resulted in population declines across their European range, despite their ecological, evolutionary, and economic significance. Information on their population demography and long-term patterns are also scarce, with focus primarily on their ammocoete freshwater phase. This is inhibiting the development of biological reference points for utilization in population monitoring programs. In the Great Lakes of North America, however, P. marinus is invasive and the high damage caused to commercial fisheries resulted in their populations being controlled through a long-term, multi-method and integrated research and management approach over the last 40 years, with the development and application of a range of novel methods. Successful knowledge transfer to Europe could therefore facilitate the monitoring of threatened populations and develop new conservation actions, including modifying migration blockages to facilitate passage, implementing adult trapping programs, and applying pheromone treatments to manipulate adult movements and behaviors. This reveals the potential utility of using invasive fish populations to inform conservation practices in native ranges, and how pheromone research could further enhance fish conservation and monitoring.

\section{KEYWORDS}

pheromone; trapping; invasion; fish passage; native; non-native

\section{Introduction}

Lampreys and hagfishes are the only surviving lineages of jawless fish (agnathan) of an ancient vertebrate group 30 that diverged $\sim 500$ million years ago (Lamb et al., 2007). As one of the oldest groups with many vertebrate characteristics (e.g., neural crest, placodes, segmented brain, skull, paired sensory organs, pharyngeal skeleton), the phylogenetic position of lampreys has made them valu-

35 able experimental models to understand the early evolution of vertebrates (e.g., Smith et al., 2013). Populations of anadromous sea lamprey Petromyzon marinus in their native ranges (e.g., Europe) tend to be threatened by multiple stressors, resulting in population declines and the implementation of generally robust conservation regulations (Renaud, 1997; Maitland et al., 2015). In the Great Lakes of North America, however, P. marinus is highly invasive and impacts commercial fisheries; as a result, their populations have been managed and controlled using long-term, multi-method and integrated research and management approaches (e.g., Christie and Goddard, 2003).

There is a paucity of examples where information collated specifically for understanding the ecology and associated management approaches for a species in its invasive range have had utility for then informing conservation strategies for that species in their native range. In this context, $P$. marinus provides a strong case study, as their invasion characteristics in the Great Lakes of North America have been studied widely in the last 40 years, resulting in considerable research investment in suitable management approaches. Consequently, there is considerable information available on their invasion biology, ecology, behavior and management in their invasive range. In contrast, in their native range in Europe, the species has high conservation designations due to their population declines that have occurred in

CONTACT Z.Guo guozq@scsio.ac.cn E Key Laboratory of Tropical Marine Bio-resources and Ecology, Guangdong Provincial Key Laboratory of Applied Marine Biology, South China Sea Institute of Oceanology, Chinese Academy of Sciences, Guangzhou 510301, China.

(c) 2016 Taylor \& Francis 
last 50 years, yet there remain considerable knowledge gaps in the provision of cost-effective conservation management strategies that aim to restore their populations to former levels. Thus, it is argued here that there are important lessons that can be gained from the work completed in their invasive range that can be at least partially applied to the European conservation context of the pecies.

Therefore, the aim of this review was to: (i) outline the importance, lifecycle, ecological roles and economic values of $P$. marinus in Europe; (ii) identify the threats to, and conservation status of, European P. marinus populations; (iii) identify the successful tools used to manage invasive P. marinus populations in the Great Lakes; and (iv) assess how the knowledge gained from this invasion management could be transferred to Europe to enhance monitoring and conservation of imperiled $P$. marinus

80 populations. In completing these objectives, this provides a strong case study of how knowledge gained for species in their invasive range can be applied to issues of conservation in their native range.

\section{Scientific importance, distribution, lifecycle and 85 ecological roles of $\boldsymbol{P}$. marinus}

\section{Scientific importance}

Due to their evolutionary significance, lampreys have been intensively studied since the early of 19th century (e.g., Beamish, 1980; Teeter, 1980), with substantial prog-

90 ress in the context of phylogeny and paleontology (e.g., Lamb et al., 2007), embryology (e.g., Kuratani et al., 2002), adaptive immunity origin (e.g., Guo et al., 2009), nervous system evolution (e.g., Green and Bronner, 2014), and genomics (e.g., Smith et al., 2013, Table 1).

95 Among 34 lamprey species in the Northern Hemisphere and 4 in the Southern Hemisphere, the sea lamprey has been studied widely due to their ease of capture (e.g., during the migration into freshwater) and their relatively large body sizes with high fecundity (Nikitina et al., 2009; Johnson et al., 2015). More recently, they have been used in studies exploring evolution and development, such as the origin and development of articulated jaws (e.g., Kuratani, 2012), photoreceptors and eye cup (e.g., Lamb et al., 2007), neural crest (Green and Bronner, 2014), and skeletal muscle of vertebrates (e.g., Kusakabe and Kuratani, 2005). In the last 5 years, modern molecular techniques have resulted in $P$. marinus being an important model species for vertebrate evolution with an emphasis on genetics and genomics, with Smith et al. (2013) presenting the first sea lamprey whole-genome sequence and assembly.

\section{Distribution}

The $P$. marinus native geographic range extends across the Northern Atlantic, where they inhabit rivers along the shores between Labrador, Canada to Florida to the West, and from Norway into the Mediterranean to the East (Renaud, 1997). Beyond its native range, the species has capitalized on the anthropogenic-engineered connectivity between the West Atlantic and the Great Lakes, where it is invasive and considered a pest (Smith and Tibbles, 1980). In its native range, however, their populations are in general decline through factors including river fragmentation, habitat loss and declining water quality (Renaud, 1997; Almeida and Quintella, 2002; Moyle et al., 2009).

In Europe, they are distributed from Varanger Fjord of Norway in the north $\left(70^{\circ} \mathrm{N}\right)$ to the Iberian Peninsula in the southwest $\left(38^{\circ} \mathrm{N}\right)$, and usually show high abundance at latitudes between $35^{\circ}$ and $45^{\circ} \mathrm{N}$ (Kelly and King, 2001; Mateus et al., 2012). The largest populations are often observed in the estuaries and large rivers

Table 1. Scientific importance, ecological roles, economic values and threats to native $P$. marinus.

\begin{tabular}{|c|c|c|}
\hline & Description & References \\
\hline Scientific importance & $\begin{array}{l}\text { An important model species for vertebrate evolution (e.g., phylogeny } \\
\text { and paleontology embryology, adaptive immunity origin, nervous } \\
\text { system evolution, genetics, and genomics) }\end{array}$ & $\begin{array}{l}\text { Kuratani et al., 2002; Lamb et al., } \\
\text { 2007; Guo et al., 2009; Green and } \\
\text { Bronner, 2014; Smith et al., } 2013\end{array}$ \\
\hline Ecological roles & $\begin{array}{l}\text { Roles include facilitating nutrient cycling in food webs, providing } \\
\text { marine-derived nutrient subsidies in freshwaters, modifying habitat } \\
\text { via ecosystem engineering, and acting as apex predators and } \\
\text { parasites. } \\
\text { Mills et al., 2003; Cochran, 2009; Nislow and Kynard, 2009; Sousa et al., } \\
\text { 2012; Guyette et al., 2014; Hogg et al., } 2014\end{array}$ & \\
\hline Economic values & $\begin{array}{l}\text { Through commercial exploitation for human food, as live foods in } \\
\text { aquaculture, and as bait for sport fishing. }\end{array}$ & $\begin{array}{l}\text { Renaud, 1997; Beaulaton et al., 2008; } \\
\text { Mateus et al., 2012; Foulds and } \\
\text { Lucas, } 2014\end{array}$ \\
\hline $\begin{array}{l}\text { Threats to their } \\
\text { native populations }\end{array}$ & $\begin{array}{l}\text { Issues include physical obstructions to migration, habitat loss (spawning } \\
\text { and nursery), pollution, fishery exploitation, and climate change. }\end{array}$ & $\begin{array}{l}\text { Igoe et al., 2004; OSPAR Commission, } \\
\text { 2009; Mateus et al., 2012; Pedro } \\
\text { et al., 2014; Maitland et al., } 2015\end{array}$ \\
\hline
\end{tabular}


flowing into the Atlantic Ocean in Western Europe, especially in Iberian Peninsula (Mateus et al., 2012), France (Beaulaton et al., 2008), and United Kingdom (Hardisty and Potter, 1971a). Coastal populations are generally lower and more sporadic in North Europe compared with Southwest Europe (ICES, 2005; Thiel et al., 2009). Recently, the sea lamprey has been recorded in north Aegean Sea (Economidis et al., 1999), Levantine

140 Sea (Cevik et al., 2010), and the North African coasts in Morocco, Algeria, and Tunisia (Clavero et al., 2014).

\section{Lifecycle}

The $P$. marinus lifecycle involves a freshwater and marine phase. Adults return from the sea to freshwater

145 between March and December when temperatures are between 10 and $19^{\circ} \mathrm{C}$, with earlier migrations tending to occur at lower latitudes (Beamish, 1980; Malmqvist, 1980a; Andrade et al., 2007; Beaulaton et al., 2008). The adults are capable of migrating hundreds of kilometers 150 upstream into freshwater to find suitable spawning habitat, during which they do not feed (Beamish, 1980; Hardisty and Potter, 1971b); thus, migration, gonad maturation and spawning rely on energy reserves developed in the marine life phase (Beamish, 1980; Hansen et al.,

155 2016).

Larvae emerge from eggs after around 14 days (Potter, 1980). The larvae-ammocoetes-then have a relatively sedentary and extended ( $\sim$ five to eight years) life stage (Beamish, 1980; Malmqvist, 1980b). Ammocoetes gener-

160 ally remain in the silt in areas of water below $2 \mathrm{~m}$ depth (e.g., Lasne et al., 2010; Taverny et al., 2012). At the end of the ammocoete phase, they metamorphose into adults (Hardisty and Potter, 1971b), and then emerge from the substrate and commence their migration to sea, usually

165 in late autumn or early winter, with completion by spring the following year, although this varies regionally (Malmqvist, 1978; Hansen et al., 2016). After typically spending 18 to 20 months at sea and attaining lengths generally of 60 to $90 \mathrm{~cm}$, they commence their

170 upstream spawning migration (Beaulaton et al., 2008; Silva et al., 2013).

\section{Ecological roles}

The ecological roles of lamprey populations mainly involve nutrient cycling in food webs (e.g., Mills et al.,

175 2003), marine-derived nutrient subsidies (e.g., Nislow and Kynard, 2009; Guyette et al., 2014), habitat modifications as ecosystem engineers (e.g., Sousa et al., 2012; Shirakawa et al., 2013; Hogg et al., 2014), prey resources for other animals (e.g., Cochran, 2009), as well as being
Table 1). Recently, for instance, studies have indicated that the returning adults provide considerable inputs of marine-derived nutrients into freshwater ecosystems via metabolic waste, unfertilized eggs, and post-spawning death and body decomposition, which are important for increasing freshwater productivity (Nislow and Kynard, 2009; Guyette et al., 2013). Whilst studies in the invasive range have investigated their potentially negative impacts, such as damage to commercially and recreationally important fishes (Christie and Goddard, 2003; Madenjian et al., 2008), there is little evidence of detrimental ecological consequences caused by native $P$. marinus populations (Docker et al., 2015).

\section{Economic importance}

Lampreys have long been considered as a gastronomic delicacy (Docker et al., 2015, Table 1), being considered as a "regal" food by the Romans in the 1st and 2nd centuries, and populations were exploited and consumed regularly in medieval Europe (Renaud, 2011). Since the 18th century, their exploitation has generally increased, with commercial exploitation now concentrated on populations in Southern Europe, such as in Portugal, Spain, and France (Beaulaton et al., 2008; Mateus et al., 2012). In addition to food, lamprey adults and ammocoetes have been used as live foods in aquaculture, and as bait for sport fishing (Renaud, 1997; Foulds and Lucas, 2014; Table 1).

\section{Threats, population status, threats and conservation in europe}

Threats to european populations

Studies on threats to $P$. marinus populations have focused on four aspects relating to their freshwater life phase: physical obstructions, habitat loss, pollution, and exploitation. The influence of climate change could also have important implications for their populations (Table 1).

\section{Physical obstructions}

Arguably, the major threat to the sustainability of $P$. marinus populations involves man-made physical obstructions that impede or block their spawning migrations, including barrages, large dams, weirs and sluices (OSPAR Commission, 2009; Maitland et al., 2015). These obstructions severely fragment their habitats and thus can strongly restrict the riverine habitats available to spawning adults (Lucas et al., 2009), as well as impede 225 the downstream movement of larvae/juveniles (Nunn 
and Cowx, 2012; Hogg et al., 2013). The blockage of migratory routes can thus significantly affect the lifetime fitness of $P$. marinus, impacting their population growth

230 and distribution, spawning success and recruitment, and affecting their vulnerability to fishing and predators (Andrade et al., 2007; Klamath River Expert Panel, 2010; Mateus et al., 2012).

The passage of river lamprey Lampetra fluviatilis over

235 anthropogenic barriers has received some attention in Europe in recent years (Masters et al., 2006; Lucas et al., 2009; Kemp et al., 2011; Russon et al., 2011; Foulds and Lucas, 2013) and this literature might be informative for P. marinus, although some caution is suggested given the

240 larger body sizes of the latter. Elevated water flow increases their migratory activity (Masters et al., 2006) and this assists their passage through barriers that otherwise can be impassable at reduced flows (Lucas et al., 2009; Foulds and Lucas, 2013). Where flows are exces-

245 sive, however, movements of both species might be hindered by their elongated body morphology and lack of paired fins that reduces their ability of negotiating highvelocity flows when compared to most other migratory fishes (Keefer et al., 2013; Foulds and Lucas, 2013). They

250 demonstrate typical anguilliform swimming under these velocities, referred to as a "burst-and-attach" pattern (Adams and Reinhardt, 2008), which is generally ineffective in high velocity areas such as weir orifices or salmonid fish passes, as these often lack suitable attachment

255 surfaces and/or the water velocity exceeds their critical swimming speeds (Adams and Reinhardt, 2008; Foulds and Lucas, 2013).

The ability of $P$. fluviatilis to utilize fish passage structures on blockages in European rivers was shown

260 by Aronsuu et al. (2015), who revealed that all individuals that used a natural-like fish-way (fish pass) were successful in passing the barrier, with individuals showing a strong preference to using this over a technical fish-way. Other studies have revealed technical fish-

265 ways are also problematic for $P$. fluviatilis to utilize (Laine et al., 1998; Lucas et al., 2009; Foulds and Lucas, 2013), with Aronsuu et al. (2015) suggesting that natural-like fish ramps might be a good solution to enhance their passage over low-head barriers. Nevertheless,

270 Lasne et al. (2015) revealed that barrier removal can be the most effective mechanism to enable $P$. marinus passage, with higher numbers of nests that were more consistently distributed occurring several years after barrier removal in a French coastal stream. This con-

275 trasts to Lucas et al. (2009) who reported that in the River Derwent, England, only $2 \%$ of adult P. fluviatilis spawners were recorded in $98 \%$ of the river's total spawning habitat as this was located above a series of impassable low-head barriers.
The important nursery habitats for ammocoetes are the depositional zones of rivers, where the mixture of sand and fine organic matter provides substrate suitable for burrowing (Igoe et al., 2004). These areas are frequently modified and/or destroyed by various anthropogenic activities, including building of dams or weirs, sand extraction, channelization, dredging, dewatering as well as the management for other fish (Oliveira et al., 2004; Mateus et al., 2012; Hogg et al., 2013). For example, dredging and channelization can directly impact larvae and ammocoetes by their removal, and indirectly by reducing the availability of nursery habitat (OSPAR Commission, 2009; Mateus et al., 2012).

Alterations in flow regimes resulting from river regulation and impoundments can also substantially impact 295 ammocoetes and adults (Oliveira et al., 2004; Close et al., 2009). For example, rivers with hydroelectric reservoirs are often subject to rapid increases of water flow in areas downstream of the dam, while the impoundment greatly decreases the flow rates more generally. As well as altering the silt deposition patterns downstream, spawning sites and larval burrows can be dewatered, resulting in nest desiccation and stranding of larvae (Almeida and Quintella, 2002). Rapid increases in water flow can also be damaging for post-metamorphic larvae, displacing eggs and ammocoetes, and disturbing their feeding behavior and movements (Moursund et al., 2003). The absence of a unidirectional current can disorient migratory adults or increase their passage time through barriers (Johnson et al., 2015). Finally, changing flow regimes can alter thermal regimes, potentially interfering with the timing and success of migration and spawning, as well as embryonic development and ammocoete survival and growth (Hogg et al., 2013).

\section{Pollution}

A wide range of pollutants has adverse effects on P. marinus populations, including those from sewage, agriculture (e.g., pesticides, herbicides), industry (e.g., heavy metals) and nutrient enrichment (eutrophication) (OSPAR Commission, 2009). Ammocoetes are particularly vulnerable to polluted interstitial water and sediments (Maitland, 2003; OSPAR Commission, 2009; Andersen et al., 2010). Heavy metal pollution was responsible for substantial decreases of populations and restricted distributions in the United Kingdom, with rivers such as the Thames and Clyde having their populations virtually eliminated through the impacts of industrial discharges during the early 20th century (Maitland, 2003). 
Eutrophication, excessive sediment inputs, and pesticides also have detrimental influences on growth and spawning. For instance, blooms of algae and bacteria can smother spawning gravels and nursery sites, resulting in anoxic conditions that can kill embryos/

335 ammocoetes in burrows (Maitland, 2003). Excessive sediment inputs (e.g., clay or fine soil) to riverbeds are likely to impact optimal habitats for larvae and also impact spawning gravels (Beamish, 2001). Pesticides have direct toxic effects on embryos and ammocoetes,

340 and can result in bioaccumulation (Renaud et al., 1995). Ammocoete and adult P. marinus has been frequently found to bioaccumulate substantially higher levels of mercury than sympatric fish (MacEachen et al., 2000; Pedro et al., 2014), whereas there have

345 been few studies examining the consequences of these contaminants and their high burdens at the population level (Andersen et al., 2010).

\section{Exploitation}

As lampreys are high-value food sources, they have been

350 subjected to heavy rates of exploitation, which can have additional impacts on already stressed populations (Renaud, 2011). Although the fisheries are managed, catch rates can be high. In France reported annual catches include 58 tons from the River Loire in 1989 and

355 a mean of 8.5 tons per year from the River Adour between 1986 and 2004 (Beaulaton et al., 2008). In the Minho River and Tagus River, Portugal, annual catches can be as high as $120,000-160,000$ and $10,000-15,000$ individuals respectively (Suíssas, 2010), with high exploi-

360 tation and illegal fishing considered as a major threat to population sustainability and conservation (Andrade et al., 2007; Mateus et al., 2012).

\section{Climate change}

Anadromous fishes, such as $P$. marinus, have complex

365 life-cycles that cover a range of physical habitats, increasing their vulnerability to climate change impacts (Lassalle et al., 2008; Lassalle and Rochard, 2009; Hansen et al., 2016). Biogeographical models based on climate change scenarios predicted that $P$. marinus would

370 decrease or be extirpated from the warmer regions of Europe (including Italian river basins, and in the majority of the river basins in the Iberian Peninsula), while the watersheds in the northern part of Europe would become the favorable habitats (Lassalle et al., 2008). Moreover,

375 the climate-driven changes in biomass and distribution of their prey/hosts might have substantial impacts on their parasitic life stage (Klamath River Expert Panel, 2010; Hansen et al., 2016).

\section{Population status}

In the last 50 years, it has generally been considered that 380 abundances in the ammocoete freshwater phase of $P$. marinus have declined (Freyhof and Brooks, 2011; Mateus et al., 2012). For example, in the United Kingdom, there were historical declines over much of its range, with extirpations from several rivers during the 1960s and 1970s (Maitland, 1980), although its range appeared to then increase in the 1980s (Joint Nature Conservation Committee, 2007). In Ireland, despite historical recordings from all suitable rivers, there has been no recent records in a number of locations where sea lamprey used to be easily observed with high densities, with suggestions of declines commencing in the 1960s (Igoe et al., 2004). In the Iberian Peninsula, Mateus et al. (2012) reported significant declines of sea lamprey populations in the second half of the 20th century, largely arising from impassable barriers. In addition, commercial catches of $P$. marinus have been decreasing in recent years, with catches in Finland, Russia, Latvia, and Estonia declining despite increases in fishing efficiency (Saat et al., 2000; Thiel et al., 2009). Nevertheless, in the Garonne Basin, Rhine, the Vilaine and the Adour of southwest France, Beaulaton et al., (2008) revealed recent increases in population size following declines at the beginning of the 1970s. It is also important to note that despite increasing surveys specifically aimed at monitoring $P$. marinus populations due to legislation, there remain few quantitative data on its population abundances at the European scale.

\section{Legislation and conservation regulations}

Generally, the status of $P$. marinus is considered as 410 "Vulnerable" in most countries of Europe (OSPAR Commission 2009; Mateus et al., 2012) and is listed on Annex B-II of the EU Habitats Directive (92/43/EEC) and Annex III of the Bern Convention (Convention on the Conservation of European Wildlife and Natural Habitats). It also is in the OSPAR convention list as a threatened and/or declining species (OSPAR Commission, 2009), and as a Long List Species in the UK Biodiversity Action Plan (Maitland, 2003). Nevertheless, it is classified overall as "Least Concern" in the IUCN Red List of Threatened Species (NatureServe, 2013), although there are different classifications among countries in Europe (Table 2).

Although there is currently no information about the dedicated and widespread conservation measures for European P. marinus populations (e.g., habitat restoration, stock transfer, captive breeding/restocking), their presence on Annex B-II of the EU Habitats 
Table 2. Conservation status of Petromyzon marinus across different European countries (updated and modified from Mateus et al. 2012).

\begin{tabular}{|c|c|c|c|}
\hline Country & IUCN status & Description & References \\
\hline Belgium & Extinct & Regionally Extinct & OSPAR Commission, 2009 \\
\hline Croatia & Extinct & Regionally Extinct & Holčik et al., 2004 \\
\hline Czech Republic & Extinct & Regionally extinct & Lusk et al., 2004 \\
\hline Denmark & Endangered & Very rare & Thiel et al., 2009 \\
\hline Estonia & Near threatened & Very rare & Thiel et al., 2009 \\
\hline Finland & No data available & Occasionally found along the south coast & Tuunainee et al., 1980 \\
\hline France & Near threatened & Regionally vulnerable & Beaulaton et al., 2008 \\
\hline Germany & Endangered & Regionally extinct & $\begin{array}{l}\text { OSPAR Commission, 2009; Thiel et al., } \\
\text { 2007; } 2009 .\end{array}$ \\
\hline Great Britain & Vulnerable & Widely distribution but declined recently & Kelly and King, 2001; Maitland, 2003 \\
\hline Ireland & Vulnerable & Annex II EU Habitats Directive & Maitland 2004; lgoe et al. 2004 \\
\hline Italy & Endangered & Regionally extinct & $\begin{array}{l}\text { Bianco and Ketmaier, 2001; Bianco, } \\
2014\end{array}$ \\
\hline Lithuania & Endangered & Regionally extinct & Repečka, 2003 \\
\hline Norway & Least Concern & Mainly distributed on south coast & Kålàs et al., 2010 \\
\hline Poland & Endangered & Regionally extinct & HELCOM, 2007; Thiel et al., 2007 \\
\hline Portugal & Vulnerable & $\begin{array}{l}\text { Vulnerable, critically endangered, and extinct } \\
\text { in different regions }\end{array}$ & Cabral et al., 2005; Mateus et al., 2012 \\
\hline Russia & Endangered & $\begin{array}{l}\text { Listed as endangered species in Red Data } \\
\text { Book of the Russian Federation }\end{array}$ & Iliashenko et al., 2000 \\
\hline Slovenia & Endangered & Very rare and regionally extinct & Povž, 2011 \\
\hline Spain & Vulnerable & $\begin{array}{l}\text { Vulnerable, critically endangered, and extinct } \\
\text { in different regions }\end{array}$ & Mateus et al., 2012 \\
\hline Sweden & Endangered & Mainly distributed in Kattegat and Sound & Gärdenfors, 2000; HELCOM, 2007 \\
\hline Switzerland & No data available & Native species & Cordillot and Klaus, 2011 \\
\hline
\end{tabular}

Directive requires establishment of an European net430 work of important and high-quality conservation natural habitats in Member States (EU Habitats Directive (92/43/EEC); Annex III of the Bern Convention). In addition, under the Habitats Directive and Natura 2000 network, there is the requirement for designating

435 Special Areas of Conservation (SACs) that incorporate Special Protection Areas (SPAs). Overall, there are 8 countries establishing SACs and/or SPAs for lampreys (i.e. United Kingdom, Scotland, Ireland, Germany, France, Spain, and Portugal). These currently contrib-

440 ute significantly to the conservation of $P$. marinus across Europe (Kelly and King, 2001; OSPAR Commission, 2009). For example, in Scotland, seven SACs have been established for lampreys to date, including P. marinus as a Priority Species in some rivers (Mait-

445 land et al., 2015). In 2004, Germany proposed SACs in parts of the estuarine Szczecin Lagoon and adjacent waters, covering the main migration route of river lampreys to their most numerous spawning sites (Thiel et al., 2009; Mateus et al., 2012). In France, over 200

450 Natura 2000 protected sites have been defined on the basis of lamprey species generally (Mateus et al., 2012). In addition, there are a number of legislative and regulatory measures in place at local and national levels to protect populations, such as the Freshwater

455 Fisheries Act (OGRS No. 61/2006) in Slovenia (Povž, 2011) and Decree No. 43/87 (DR, 1987) and Decree No. 7/2000 (DR, 2000) in Portugal (Mateus et al.,
2012), the latter being important in regulating their exploitation through closed fishing periods (January to the end of April), landing sizes (minimum size $35 \mathrm{~cm}$ ) 460 and catches (maximum 30 individuals per day per registered fisherman) (Mateus et al., 2012).

In addition, much of the recent focus of work completed in Europe on P. marinus in a conservation context has been on monitoring their populations. For example, in the United Kingdom, work initially developed population monitoring techniques, where the recommended focus was on the ammocoete stages, with hand-held electric fishing techniques being used to estimate their densities in appropriate habitats, as identified in River Habitat Surveys (Harvey and Cowx, 2003). Other techniques for sampling ammocoetes have also been developed since then, including adaptation of surber samplers used for macro-invertebrate sampling (e.g., Lasne et al., 2010). Whilst Harvey and Cowx (2003) suggested adults could be monitored through use of existing infrastructure on river impoundments that measure passage of migrating salmonid fishes, they did not recommend the use of counting spawning nests (redds). However, Pinder et al. (2015) suggested redd counts could be used as a rapid assessment tool for measuring relative adult numbers and, in particular, can highlight areas of river that provide excellent spawning areas and identify the negative consequences of impoundments on the distri- 485 bution of redd within river catchments. 


\section{Conclusions on P. marinus in europe}

European populations are threatened by a number of environmental and anthropogenic stressors. Whilst pro-

490 tected by a range of legislation, knowledge on population sizes (ammocoete and adults) is limited, inhibiting the construction of long-term monitoring programs and conservation measures. Indeed, monitoring of European populations largely ignores the adult phase of the life-

495 cycle, at least in a coordinated manner, with focus primarily on measuring ammocoete production and recruitment. Evidence from the invasive range of the Great Lakes, however, suggests that a number of approaches could be implemented in Europe that could

500 substantially increase knowledge on European population demographics and ecology, and enhance conservation practices.

\section{Invasive $P$. marinus in the north american great lakes and the relevance to conservation in europe}

\section{Invasive P. marinus in the north american great lakes}

Historically, $P$. marinus were unable to enter the Great Lakes of North America as the Niagara Falls provided a

510 natural barrier to their upstream movement, confining them to Lake Ontario and preventing them from entering the remaining four lakes. However, in the late $1800 \mathrm{~s}$ and early 1900s, improvements were made to the Welland Canal, bypassing Niagara and providing a shipping

515 connection between Lakes Ontario and Erie providing a dispersal route to the remaining lakes. Sea lamprey was first recorded in a Canadian tributary to Lake Ontario in 1835 (Lark, 1973), and was then found throughout the lake in the late 1900s (Christie, 1973). It was then

520 detected in Lake Erie in 1921, Lake St Clair in 1934, Lake Michigan in 1936, Lake Huron in 1937, and Lake Superior in 1938 (Smith and Tibbles, 1980; Christie and Goddard, 2003).

Impacts arising from their invasion include damage to

525 local fisheries through its parasitism of the Great Lakes' commercial fisheries (e.g., Lake Superior, Heinrich et al., 2003; Lake Ontario, Larson et al., 2003; Lake Huron, Morse et al., 2003). In the upper of the Great Lakes, $P$. marinus abundances increased markedly soon after their

530 colonization and coincided with population declines in their host species (Smith and Tibbles, 1980; Morse et al., 2003). For example, in Lake Huron, lake trout catches declined from more than $2268 \mathrm{t}$ in 1938 to $76 \mathrm{t}$ in 1954, and in Lake Michigan, from $2948 \mathrm{t}$ in 1944 to $181 \mathrm{~kg}$ in

5351953 (Smith and Tibbles, 1980). In Lake Superior, catches were as high as $2041 \mathrm{t}$ in 1950 , but drastically decreased to $227 \mathrm{t}$ in 1960 (Baldwin and Saalfeld, 1962). The resulting decrease in the abundance of piscivorous fish species also impacted food web structure, extending the invasion impacts beyond direct fishery costs (Smith and Tibbles, 1980; Mills et al., 2003).

\section{Managing invasive P. marinus in the great lakes}

The first serious attempt to control $P$. marinus in the Great Lakes was in 1950 with the installation of mechanical barriers along Lake Huron to block spawning migrations; by 1962, electrical barriers were installed in 162 tributaries of the Great Lakes for this purpose (Smith and Tibbles, 1980). Numerous cooperative programs have been developed and implemented by fisheries management agencies in both Canada and the 550 United States to control populations and provide fishery protection, with Great Lakes Fishery Commission (GLFC) established in 1955 (Christie and Goddard, 2003; http://www.glfc.org). Sawyer (1980) introduced the concept of Integrated Pest Management and advocated its application to P. marinus, with the specific concept and framework of Integrated Management of Sea Lamprey adopted subsequently (Davis et al., 1982). Recently, the Integrated Sea Lamprey Control Program has been implemented (http://www.glfc.org/pubs/Special Pubs/StrategicVision2012.pdf; http://www.glfc.org). Overall, a great effort has been made to implement the sea lamprey control program with, for example, an average of $\$ 14$ million per annum spent between 2000 and 2004 (approximately $\$ 7.5 \mathrm{M}$ for control, $\$ 4.0 \mathrm{M}$ for assessment and $\$ 2.5 \mathrm{M}$ for research) (Jones, 2007). Some of the prominent management approaches in the sea lamprey programs are outlined in Table 3.

In combination, these approaches (Table 3) have successfully suppressed populations of sea lamprey (Smith and Tibbles, 1980; Heinrich et al., 2003). For instance, the extirpation has been achieved in 20 of 57 streams with historical records of production in the Lake Ontario catchment (Larson et al., 2003), and the abundance of spawning individuals decreasing from 150300,000 to 44,000 between 1985 and 1999 (Mullett et al., 2003). In Lake Huron, P. marinus abundance was reduced by almost $85 \%$ between 1970 and 1999 (Morse et al., 2003). More recently, the adult sea lamprey abundance in 2014 showed a substantial reduction when compared with the 2012 and 2013 estimates (http:// www.glfc.org/sealamp/ANNUAL_REPORT_2014.pdf). Concomitantly, the annual production of large and highquality commercial important species has steadily increased (Larson et al., 2003; see annual report at http:// www.glfc.org). Some of the approaches used within the sea lamprey control program indicate the extent to which 
Table 3. Examples of methods used to control/ monitoring invasive Petromyzon marinus in the North American Great Lakes (adapted from Christie and Goddard 2003).

\begin{tabular}{|c|c|c|c|}
\hline Method & Rationale and life-stage targeted & Interest for conservation in Europe & References \\
\hline Barrier construction & $\begin{array}{l}\text { Prevent upstream passage of spawning } \\
\text { adults }\end{array}$ & $\begin{array}{l}\text { Modify and/or dismantle the existing } \\
\text { barriers to facilitate passage by } \\
\text { migrating adults }\end{array}$ & $\begin{array}{l}\text { Hunn and Youngs, 1980; Lavis } \\
\text { et al., } 2003\end{array}$ \\
\hline Trapping & $\begin{array}{l}\text { Capture and physically remove either } \\
\text { juvenile or adults, and assess } \\
\text { population sizes }\end{array}$ & $\begin{array}{l}\text { Provide a cost-effective method for } \\
\text { monitoring, and supply live adults } \\
\text { for translocations and captive } \\
\text { breeding programs }\end{array}$ & $\begin{array}{l}\text { Johnson et al., 2005; Bravener } \\
\text { and McLaughlin, } 2013\end{array}$ \\
\hline $\begin{array}{l}\text { Application of lampricides } \\
\text { (3-Trifluoromethyl-4- } \\
\text { nitrophenol and 2, } \\
\text { 5-dichloro-4-nitro- } \\
\text { salicylanilide) }\end{array}$ & $\begin{array}{l}\text { Manipulate adult behaviors in } \\
\text { freshwater, increase trapping } \\
\text { efficiency }\end{array}$ & $\begin{array}{l}\text { Potential for manipulating lamprey } \\
\text { behaviors to enable increased } \\
\text { sampling efficiency, providing } \\
\text { increased data on population status } \\
\text { to inform conservation strategies. }\end{array}$ & Dawson, 2003 \\
\hline $\begin{array}{l}\text { Application of migratory } \\
\text { and mating } \\
\text { pheromones }\end{array}$ & $\begin{array}{l}\text { Improve trapping efficiency; attract } \\
\text { migrating adults into specific areas } \\
\text { for elimination or lampricide } \\
\text { treatment }\end{array}$ & $\begin{array}{l}\text { Attract the migrating adults into high } \\
\text { quality areas or direct them away } \\
\text { from poor habitats in the purpose } \\
\text { of conservation. }\end{array}$ & $\begin{array}{l}\text { Li et al., 2003; Sorensen and } \\
\text { Vrieze, 2003; Johnson et al., } \\
\text { 2013; } 2015 .\end{array}$ \\
\hline Release of sterile males & $\begin{array}{l}\text { Reduce reproduction efficiency of } \\
\text { adults }\end{array}$ & No specific interest for conservation. & Twohey et al., 2003 \\
\hline Chemosensory alarm cues & $\begin{array}{l}\text { Natural repellents to force individuals } \\
\text { into management areas }\end{array}$ & $\begin{array}{l}\text { Direct adults from low quality habitats/ } \\
\text { streams and direct to areas of } \\
\text { favorable habitat. }\end{array}$ & $\begin{array}{l}\text { Imre et al., 2010; } \\
\quad \text { Wagner et al., } 2011\end{array}$ \\
\hline
\end{tabular}

P. marinus populations can be manipulated for management purposes and thus the following sub-sections high-

590 light those that have relevance to monitoring and/or conserving European populations.

\section{Management of migration blockages}

In sea lamprey control programs, barriers have been an important non-chemical approach used to prevent

595 migrating adults from accessing spawning habitats, with the general aims of disturbing their spawning potential and reducing the number of streams used for ammocoete production (Lavis et al., 2003). The effective use of barriers has also reduced the use of lampricide applications

600 and other control program costs (Hunn and Youngs, 1980). Several types of barriers have been used to block migration routes, including the "standard" low-head barriers, adjustable-crest barriers, velocity barriers, and electrical barriers (Lavis et al., 2003).

605 Low-head barriers are most often used and have a fixed-crest height and overhanging lip to maintain a vertical drop of a minimum of $30 \mathrm{~cm}$ from headwater to tailwater during the period of lamprey migration, as this appears to prevent their passage (Hunn and Youngs,

610 1980). These were frequently constructed on streams in strategic locations throughout the Great Lakes basin, with around 61 installed or modified between 1958 and 1999, with others added in 90 streams after 1999 (Lavis et al., 2003). Approximately 20 dams were also estab-

615 lished for other purposes that have since been modified to also prevent adult movement, and there are also a number of existing dams and traditional fish passes that limit $P$. marinus access to spawning habitat (Lavis et al., 2003; McLaughlin et al., 2007).

Man-made barriers were identified as a major threat to European populations, with evidence suggesting fish passes are only effective for passage when they mimic natural conditions, with salmonid fish passes often ineffective (e.g., Aronsuu et al., 2015). Where barrier removal is impossible, then modification to barrier height could be a more sustainable solution to blockages in European rivers. Evidence from the Great Lakes suggests that modifications to low-head barriers in Europe would need to ensure a vertical drop of less than $30 \mathrm{~cm}$ (headwater to tailwater) to provide the maximal capacity for P. marinus passage (Lavis et al., 2003). The vertical height of the fixed-crest barriers should be considered carefully; based on adjustable-crest barriers in the Great Lakes, the crest should be lowered during the period of upstream migration to make them passable and also during the period of downstream movement of larvae/juveniles. Modification of existing high-crest barriers to adjustable-crest barriers would require cost-benefit decisions based on lamprey conservation versus river management. Additionally, modification of existing fish passes should be considered to facilitate passage by migrating adults (Keefer et al., 2013).

\section{Trapping}

Trapping to remove migrating adults prior to spawning has been an integral component of sea lamprey control programmes (Johnson et al., 2005; McLean, 2014) and provides a cost-effective method compared to chemical 
application, especially in large rivers (McLean, 2014). The trapping can also be highly selective for $P$. marinus

650 (McLaughlin et al., 2007). Trapping data also indicate the spatial and temporal dynamics of the $P$. marinus populations, enabling population estimates and the costeffectiveness assessment of the sea lamprey control programs (Mullett et al., 2003; Jones, 2007).

655 There are two types of sea lamprey traps used, permanent and portable (McLaughlin et al., 2007). Permanent traps are often installed into barriers or fish passes, and are usually constructed from concrete or steel in a square or rectangular shape. Developments in trap design have

660 resulted in $P$. marinus specific traps, incorporating decreasing gradations of funnel opening size (Johnson et al., 2005; McLaughlin et al., 2007). Transportable traps are usually sheet mesh cages, and temporally placed at a fixed structure in rives during the migration period and

665 removed afterwards (McLaughlin et al., 2007). Estimates of annual trapping efficiency using mark-recapture methods suggest around $40-70 \%$ of adults can be trapped (Haeseker et al., 2007). Klar and Young (2002) revealed an average of $39 \%$ of migrating sea lampreys

670 were trapped overall in the Great Lakes, with estimates as high as 60 to $80 \%$ in some rivers. Variability in the efficiency of individual traps is also apparent with, for example, it being as low $10 \%$ for some traps in the St. Marys River (Bravener and McLaughlin, 2013).

675 This experience and knowledge on adult trapping has high relevance to Europe where monitoring currently focuses primarily on the ammocoete (larvae) life stage, resulting in very limited knowledge of adult numbers. Thus, application of trapping for adult monitoring across

680 European rivers could provide a cost-effective method for monitoring programs to assess geographic distribution, population size/density, population structure, and spatial-temporal population dynamics, providing baseline data on which conservation programs could be

685 based (Mullett et al., 2003; Jones, 2007). Trapping can also supply a large number of live adults, thus enabling translocations (e.g., reintroductions in regions where the native $P$. marinus is extinct and relocations to enhance highly endangered small populations) as well as the

690 movement of trapped individuals from below blockages to above them.

\section{Pheromone use}

Two types of pheromones play key roles in facilitating the completion of the $P$. marinus life cycle, migratory

695 pheromones (Sorensen and Vrieze, 2003; Sorensen and Hoye, 2007) and mating pheromones (Li et al., 2003; Johnson et al., 2006; 2013; 2015). Migratory pheromones, a mixture of the unique bile acids that comprise at least three sulfated steroids (petromyzonamine disulphate (PADS), petromyzosterol disulphate (PSDS), and petromyzonol sulphate (PS)), are released by stream-resided conspecific larvae or perhaps other lampreys to attract the migratory adults of both sexes when they undertake nocturnal migrations into streams for spawning (Sorensen and Vrieze, 2003). The mating pheromone is also a bile acid secreted by spermiating males that is unequivocally identified as $7 \alpha, 12 \alpha, 24$-trihydroxy- $5 \alpha$ cholan-3-one 24-sulfate (3 keto-petromyzonol sulfate; $3 \mathrm{kPZS})$ and $7 \alpha, 12 \alpha$-dihydroxy-5 $\alpha$-cholan-3-one-24-oic acid (3-keto allocholic acid, 3kACA) (Yun et al., 2003). It is highly attractive to ovulating females and is believed to guide ovulated females to nests, stimulate spawning readiness, and signals participation in nest construction (Li et al., 2003; Johnson et al., 2009; Walaszczyk et al., 2013). Similarly, the sexually mature female lampreys also appear to release a pheromone to attract spermiating male conspecifics, whilst the structure of this pheromone has yet to be identified and it is not seriously considered in sea lamprey control programs (Teeter, 1980).

The application of pheromones to manipulate sea lamprey behaviors appears a useful and cost-effective control technique (e.g., Johnson et al., 2005; 2006; 2009; 2013; 2015; Wagner et al., 2006; Johnson et al., 2013; Walaszczyk et al., 2013; Meckley et al., 2014). They have several advantages, including minute quantities of pheromone eliciting powerful behavioral responses over long distances, specificity at the species level, naturally occurring without toxicity, synthetic and purified at a reasonable cost, and economical to develop and apply with simple logistics (Li et al., 2003, 2007; Twohey et al., 2003; Sorensen and Hoye, 2007). Correspondingly, they have been applied in various ways for facilitating the control of $P$. marinus, including use as attractants to improve trapping efficiency (Sorensen and Stacey, 2004; Li et al., 2007; Johnson et al., 2009; 2013; 2015). For example, in the Trout River, Michigan, Wagner et al. (2006) found adults were three times more likely to enter traps in the streams treated with a migratory pheromone compared with the adjacent un-baited traps. In addition, adults can arrive in estuaries a number of months before actually commencing upstream movement and so use of pheromone-based traps in the lower reaches of spawning rivers could prolong the trapping season and increase the number of adults removed (Sorensen and Vrieze, 2003; Sorensen and Hoye, 2007; Meckley et al., 2014).

Migratory and mating pheromones can also be used to attract the migrating adults into specific rivers (e.g., those where lampricide treatments are to be used) or direct them away from specific rivers (e.g., those with excellent spawning habitat) (Li et al., 2003; Sorensen and Vrieze, 2003). They can be used to disrupt mating

\section{0} 705 710 715

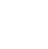


behavior and reduce reproductive success ( $\mathrm{Li}$ et al., 2003). For example, as male mating pheromones serve as the strong cues to assist the ovulating females in locating

755 nets and stimulating spawning readiness, these could be used to confuse and confound mating signals to disrupt the communication between spawning-phase males and females. Several strategies have been suggested, including releasing the synthetic antagonists, camouflaging the

760 pheromone signals released by spermiating males, creating imbalance in sensory inputs, generating sensory adaptation, and strengthening competition synthetic disrupters in relation to the natural pheromone (Li et al., 2003).

765 These applications of pheromones in the invasive range suggest numerous potential applications for monitoring and conserving P. marinus in Europe (Hansen et al., 2016). Where trapping is implemented as a monitoring and translocation tool then migratory and mating

770 pheromones could enhance trap efficiency. The potential for substantially increasing the capture of mature adults would be especially helpful for captive breeding programs. The pheromones could be used to direct migrating adults into selected areas where spawning and/or

775 nursery habits have been enhanced, and into tributaries with few impediments to migration and where water quality is high and flows undisturbed. They could also be used to attract spawning sea lampreys into rivers where the ancestral population is extinct but the river is now

780 suitable for colonization. The measurement of concentrations of migratory and mating pheromones could also be used to assess their population status as indicators of larval presence/absence/abundance, spawning population size, as well as for measuring the timing and dura-

785 tion of migration and spawning runs (Sorensen and Vrieze, 2003; Sorensen and Hoye, 2007; Johnson et al., 2009).

The body of work completed to date on pheromone applications in the Great Lakes success is thus encourag-

790 ing in the context of their invasion management, but also suggest there are applications for its use in a European conservation context. Notwithstanding, there are potential disadvantages and risks that could arise from its application in the wild that requires further attention.

795 For example, there are limited understandings of how the effects of environmental factors, such as temperature and water velocity, affect the effectiveness of pheromone treatments, and how the potential presence of xenobiotics in individuals will affect their responses (Chung-

800 Davidson et al., 2011). There are also potential risks of the application of chemicals within aquatic ecosystems, for which further research might be necessary in order to better understand impacts on other species and communities, and to design best-practice guidance and criteria
(Fine et al., 2004; Li et al., 2007; Chung-Davidson et al., 805 2011).

\section{Chemosensory alarm cues}

Several recent studies have demonstrated $P$. marinus is sensitive to a group of biologically relevant odorants, such as the conspecific deathly odor (Wagner et al., 2011), conspecific injury-released alarm cues (Imre et al., 2014), heterospecific damage-released stimuli (Imre et al., 2014; Imre and Brown, 2014), and predator chemosensory cues (Di Rocco et al., 2014). In their invasive range, these could be used as repellents to manipulate migratory behaviors and thus have potential application to population control (Imre et al., 2010), for example, preventing migratory adults from accessing the streams where spawning habitats or nursery sites are of high quality, where there are few physical barriers and/ or where traps and lampricide treatments are difficult to deploy. Used in conjunction with the pheromone-based management, migrating adults could be concentrated in selected rivers where control methods are most effective (Imre et al., 2010). The potential application of chemosensory alarm cues for conserving P. marinus in Europe is lower than for pheromones, but do include application to divert migrating adults away from areas sub-optimal to spawning and/ or nursery habitats, and encourage movement into more favorable areas. In addition, similar concerns would exist on their application in Europe as were highlighted for pheromone use.

\section{Discussion}

Threats to $P$. marinus populations remain throughout their European range, primarily migration blockages, and habitat fragmentation and loss. Although populations have protection through legislation from national to European levels, populations remain vulnerable due to their complex lifecycle, with this vulnerability only likely to increase with climate change due to predicted hydrological alterations that result from more unpredictable precipitation patterns (Morrongiello et al., 2011). In Europe, much of the focus on P. marinus has been on populations in Great Britain (e.g., Harvey and Cowx, 2003; Lasne et al., 2010; Pinder et al., 2015), France (e.g., Beaulaton et al., 2008) and the Iberian Peninsula (e.g., Mateus et al., 2012). Where populations are monitored, focus is often on the ammocoete stage, where electric fishing techniques tend to be recommended for measuring their densities in appropriate habitats (Harvey and Cowx, 2003). For determining the size of the inward spawning migration run of adults then suggested techniques include redd (nest) counts and application of video 
monitoring on fish passes (e.g., Lasne et al., 2015; Pinder 855 et al., 2015). In the tidal River Garonne, France, the species is commercially exploited using drifting trammel nets and unbaited pots, and these provide catch returns from which statistics are produced to highlight patterns in their relative abundance and provide adults for bio-

860 metric characteristics (Beaulaton et al., 2008). Indeed, since the end of the 1990s to 2005 (the end of the study period), they revealed increased catches and thus an indication of increased run sizes (Beaulaton et al., 2008). The use of catch statistics elsewhere in Europe to monitor

865 populations in this manner is prevented by there being no operational professional fisheries due to the conservation status of the species.

The $P$. marinus population monitoring effort in Europe is thus highly fragmented and restricted to a rela-

870 tively small number of river basins. For example, Beaulaton et al., (2008) compared P. marinus biometric data from the River Garonne with other European rivers, and comparisons were limited to the Rivers Elbe (Germany), Rhine (Netherlands), Shannon (Ireland), Severn

875 (Great Britain), Scorff, Vilaine, Loire and Adour (France), and the Lima and Mondego (Portugal), with some of these data being relatively dated, such as for the Severn (Holcik, 1986). There is thus a relatively low monitoring effort describing the presence/absence of this

880 species in other regions of Europe, such as around the Baltic Sea (Thiel et al., 2009), Aegean Sea (Economidis et al., 1999), Ireland (Igoe et al., 2004), Levantine Sea (Cevik et al., 2010), and North African coasts (Clavero et al., 2014). This suggests there are considerable gaps in

885 knowledge in Europe on their overall population patterns, demographics, biology and ecology. Similar spatial and biological data are already used in Europe to construct biological reference points for application to monitoring programs of migratory fishes such as Salmo salar

890 (e.g., Aprahamian et al., 2006). Thus, we argue that these knowledge gaps on $P$. marinus populations are impinging the development of strategies to manage their populations sustainably, particularly in their freshwater stages, where managers have the ability to implement rel-

895 atively cost-effective methods.

The evidence presented here suggests that their population monitoring in Europe, and subsequently their conservation management where populations are shown to be under threat, can be strongly informed from the

900 transfer of knowledge from their invasion ecology and management in the Great Lakes (Table 3). Application of knowledge on modifying blockages to migration, the use of trapping migrating adults to monitor the adult component of populations, the use of translocations and

905 captive-rearing programs, and the application of pheromone and chemosensory alarm cues to, for instance, manipulate spatial use of river catchments and encourage migration into rivers with extirpated populations, could provide substantial benefits for both population monitoring and enhancement (Table 3). Their application would already greatly benefit from the research investments made in the Great Lakes, reducing the costs of their implementation in Europe. Nevertheless, the application of such tools still brings a requirement for investment in Europe in order to prove proof-of-concept of some of the methods in a European context, given differences in, for example, environmental conditions, and magnitudes of fishery pressure and anthropogenic impacts. Indeed, the $\$ 14$ million invested per annum in the sea lamprey control program between 2000 and 2004 (Jones, 2007) is a level of investment that is likely to be unrealistic in a European context, particularly in the current economic climate (the cost of sea lamprey management in the Great Lakes has doubled since 2003). Correspondingly, it is recommended that initial knowledge transfer to Europe involves relatively simple steps to achieving better data on aspects of their populations, such as trapping of migrating adults at river mouths for assessment of their timing and run numbers, with some of these fish then able to tagged, enabling telemetry techniques to be employed briefly to track their spawning movements and behaviors.

The outputs here also reveal the potential of manipulating populations and capture methods with pheromones. Although most fish pheromone systems remain unstudied, those completed highlight the strong connection between individual behaviors and pheromones, and their potential application to management (Burnard et al., 2008). Consequently, outputs from the P. marinus pheromone research reveal the high potential of this research area to create new knowledge on the evolution, behavior, ecology and conservation management of fishes.

Lastly, these outputs indicate the high utility of studies of non-native species in their invasive range to inform that species' monitoring, conservation and management in their native range, particularly when the native populations are vulnerable to extirpations and local extinctions. Accepting that the invasive populations are reacting to novel environments and interacting with different species, they nevertheless provide potential opportunities for large-scale field experiments that are unlikely to be possible in the native range where populations are threatened. For example, in some South American regions such as Patagonian Chile, salmonid fishes such as Atlantic salmon Salmo salar are invasive following their escape from aquaculture facilities (Schroder and Garcia de Leaniz, 2011). Yet in their native European range, they are listed on Annex II of the EU Habitats 
960 Directive, with Jonsson and Jonsson (2009) suggesting climate change will result in the northward movement of their thermal niche and decreased production and population extinction in the southern part of the distribution areas. Given the considerable research and conservation

965 challenges associated with avoiding aspects of this, information and research opportunities from invasive regions could be highly valuable. Thus, conservation biologists studying vulnerable species with extended invasive ranges should collaborate closely with relevant invasion ecologists to inform and design their conservation management plans. Although both will have opposing objectives for the management of the species, the knowledge exchange will be invaluable in achieving their management goals.

\section{Funding}

The research was financially supported by National Natural Science Foundation of China (31402316), Scientific Research Foundation for the Returned Overseas Chinese Scholars, State Education Ministry, and Erasmus Mundus Action 2 TECHNO 980 Project, European Commission to ZG.

\section{References}

Adams, R. D., and U. G. Reinhardt. Effects of texture on surface attachment of spawning-run sea lampreys Petromyzon marinus: a quantitative analysis. J. Fish. Biol., 73: 14641472 (2008).

Almeida, P. R., and B. R. Quintella. Larval habitat of the sea lamprey (Petromyzon marinus L.) in the River Mondego (Portugal), pp. 121-130 In: Freshwater Fish Conservation: Options for the Future (Collares-Pereira, M. J., M. M.

990 Coelho, and I. G. Cowx, Eds.). Oxford: Fishing News Books, Blackwell (2002).

Andersen, H. B., R. S. Caldwell, J. Toll, T. Do, and L. Saban. Sensitivity of lamprey ammocoetes to six chemicals. Arch. Environ. Con. Tox., 59: 622-631 (2010).

995 Andrade, N. O., B. R. Quintella, J. Ferreira, S. Pinela, and P. R. Almeida. Sea lamprey (Petromyzon marinus L.) spawning migration in the Vouga river basin (Portugal): poaching impact, preferential resting sites and spawning grounds. Hydrobiologia, 582: 121-132 (2007).

1000 Aprahamian, M. W., R. J. Wyatt, and B. A. Shields. Use of biological reference points for the conservation of Atlantic salmon, Salmo salar, in the River Lune, North West England. Fish. Man. Ecol., 13: 21-30 (2006).

Aronsuu, K., T. J. Marjomäki, J .Tuohino, K. Wennman, R.

1005 Vikström, and E. Ojutkangas. Migratory behaviour and holding habitats of adult river lampreys (Lampetra fluviatilis) in two Finnish rivers. Boreal. Environ. Res., 20: 120-144 (2015).

Baldwinn, N. S., and R. W. Saalfeld. Commercial fish production in the Great Lakes, 1867-1960. Great Lakes Fish Com-

1010 mittee Technology Report 3, p 166 (1962).

Beamish, F. W. H. Biology of the North American anadromous sea lamprey, Petromyzon marinus. Can. J. Fish Aquat. Sci., 37: 1924-1943 (1980).
Beamish, R. J. Updated status of the Wancouver Island lake lamprey, Lampetra macrostoma, in Canada. Can. Field. Nat., 115: 127-130 (2001).

Beaulaton, L., C. Taverny, and G. Castelnaud. Fishing, abundance and life history traits of the anadromous sea lamprey (Petromyzon marinus) in Europe. Fish Res., 92: 90-101 (2008).

Bianco, P. G. An update on the status of native and exotic freshwater fishes of Italy. J. Appl. Ichthyol., 30: 62-77 (2014).

Bianco, P. G., and V. Ketmaier. Anthropogenic changes in the freshwater fish fauna of Italy, with reference to the central region and Barbus graellsii, a newly established alien species of Iberian origin. J. Fish. Biol., 59: 190-208 (2001).

Bravener, G. A., and R. L. McLaughlin. A behavioural framework for trapping success and its application to invasive sea lamprey. Can. J. Fish Aquat. Sci., 70: 1-9 (2013).

Burnard, D., R. E. Gozlan, and S. W. Griffiths. The role of pheromones in freshwater fishes. J. Fish. Biol., 73: 1-16 (2008).

Cabral, M. J., J. Almeida, P. R. Almeida, and T. Dellinger, et al. In: Livro Vermelho dos Vertebrados de Portugal. Lisbon: Instituto de Conservação da Natureza (2005).

Cevik, C., D. Ergueden, and N. Tekelioglu. Confirmation of the presence of the sea lamprey, Petromyzon marinus Linnaeus, 1758 in the Levantine Sea (Petromyzon iformes: Petromyzonidae). Zool. Mid. East., 49: 107-108 (2010).

Christie, G. C., and C. I. Goddard. Sea Lamprey International Symposium (SLIS II): Advances in the integrated management of sea lamprey in the Great Lakes. J. Great. Lakes. Res., 29: 1-14 (2003).

Christie, W. J. A review of the changes in the fish species composition of Lake Ontario. Great Lakes Fish Committee Technology Report 23, pp 35-41 (1973).

Chung-Davidson, Y. W., M. Huertas, and W. Li. A review of research in fish pheromones, pp. 467-482. In: Chemical Communication in Crustaceans (Breithaupt, T., and M. Thiel, Eds.). Springer Science+Business Media (2011).

Clavero, M., B. Adrados, J. Calzada, and M. Jácome-Flores. On the presence of Petromyzon marinus in Oued Moulouya (Morocco). Cybium, 38: 307-308 (2014).

Close, D. A., K. P. Currens, A. Jackson, et al. Lessons from the reintroduction of a noncharismatic, migratory fish: Pacific Lamprey in the Upper Umatilla River, Oregon, pp 233-253. In: Biology, Management, and Conservation of Lampreys in North America (Brown, L. R., Chase, S. D., Mesa, M. G., Beamish, R. J., and Moyle, P. B., Eds). American Fisheries Society, Symposium 7 Bethesda (2009).

Cochran, P. A. Predation on lampreys, pp 139-151. In Biology, management, and conservation of lampreys in North America (Brown, L. R., Chase, S. D., Mesa, M. G., Beamish, R. J., and Moyle, P. B., Eds.). American Fisheries Society, Symposium 72, Bethesda (2009).

Cordillot, F., and G. Klaus. Threatened Species in Switzerland. Red List Synthesis Report, Status 2010. Federal Office for the Environment, Bern. State of the environment No.1120, p 111 (2011).

Davis, J., P. Manion, L. Hanson, B. G. H. Johnson, A. K. Lamsa, W. McCallum, H. Moore, and W. Pearce. A Strategic Plan for Integrated Management of Sea Lamprey in the Great Lakes. Ann Arbor, MI: Great Lakes Fish. Comm (1982).

Dawson, V. K. Environmental fate and effects of the lampricide Bayluscide: A review. J. Great. Lakes. Res., 29: 475-492 (2003). 
Di Rocco, R. T., C. F. Belanger, I. Imre, G. E. Brown, and N. S. Johnson. Daytime avoidance of chemosensory alarm cues by adult sea lamprey (Petromyzon marinus). Can. J. Fish Aquat. Sci., 71: 824-830 (2014).

1080 Docker, M. F., J. B. Hume, and B. J. Clemens. Introduction: A Surfeit of Lampreys, pp. 1-30 In Lampreys: Biology, Conservation and Control, Vol. 1 (M. F. Docker, Eds.). Dordrecht: Fish and Fisheries Series, 37. Springer Science + Business Media BV (2015).

1085 DR (Decreto Regulamentar) 43/87 de 17 de Julho. pp. 28142830 In: Diário da República (Série I) 162. Lisbon: Ministério da Agricultura, Pescas e Alimentação (1987).

DR (Decreto Regulamentar) 7/2000 de 30 de Maio. pp. 24942509 Diário da República (Série I) 125. Lisbon: Ministério

1090 da Agricultura, do Desenvolvimento Rural e das Pescas (2000).

Drevnick, P. E., M. J. Horgan, J. T. Oris, and B. E. Kynard. Ontogenetic dynamics of mercury accumulation in Northwest Atlantic sea lamprey (Petromyzon marinus). Can. J.

1095 Fish. Aquat. Sci., 63: 1058-1066 (2006).

Economidis, P. S., A. Kallianiotis, and H. Psaltopoulou. Two records of sea lamprey from the north Aegean Sea. J. Fish Biol., 55: 1114-1118 (1999).

Fine, J. M., L. A. Vrieze, and P. W. Sorensen. Evidence that pet-

1100 romyzontid lampreys employ a common migratory pheromone that is partially comprised of bile acids. J. Chem. Ecol., 30: 2091-2110 (2004).

Foulds, W. L., and M. C. Lucas. Paradoxical exploitation of protected fishes as bait for anglers: evaluating the lamprey

1105 bait market in Europe and developing sustainable and ethical solutions. PLoS One 96: e99617 (2014).

Foulds, W. L., and M. C. Lucas. Extreme inefficiency of two conventional, technical fishways used by European river lamprey (Lampetra fluviatilis). Ecol. Engin., 58: 423-433 (2013).

Freyhof, J., and E. Brooks. European Red List of Freshwater Fishes. Luxembourg: Publications Office of the European Union (2011).

Gärdenfors, U. The 2000 Red List of Swedish Species. Uppsala,

1115 Sweden: ArtDatabanken, SLU (2000).

Green, S. A., and M. E. Bronner. The lamprey: A jawless vertebrate model system for examining origin of the neural crest and other vertebrate traits. Differentiation, 87: 44-51 (2014).

1120 Guo, P., M. Hirano, B. R. Herrin, J. Li, C. Yu, A. Sadlonova, and M. D. Cooper. Dual nature of the adaptive immune system in lampreys. Nature, 459: 796-801 (2009).

Guyette, M.Q., C. S. Loftin, and J. Zydlewski. Carcass analog addition enhances juvenile Atlantic salmon (Salmo salar)

1125 growth and condition. Can. J. Fish Aquat, Sci., 70: 860-870 (2013).

Guyette, M. Q., C. Loftin, J. Zydlewski, and R. Cunjak. Carcass analogues provide marine subsidies for macroinvertebrates and juvenile Atlantic salmon in temperate oligotrophic streams. Freshwater Biol., 59: 392-406 (2014).

Haeseker, S. L., M. L. Jones, R. M. Peterman, J. R. Bence, W. Dai, and G. C. Christie. Explicit consideration of uncertainty in Great Lakes fisheries management: Decision analysis of sea lamprey (Petromyzon marinus) control in the St.

1135 Marys River. Can. J. Fish Aquat. Sci., 64: 1456-1468 (2007). Hansen, M. J., C. P. Madenjian, J. W. Slade, T. B. Steeves, P. R. Almeida, and B. R. Quintella. Population ecology of the sea lamprey (Petromyzon marinus). as an invasive species in the Laurentian Great Lakes and an imperiled species in Europe. Rev. Fish Biol. Fisheries., doi 10.1007/s11160-0169440-3 (2016).

Hardisty, M. W., and I. C. Potter. The general biology of adult lampreys, pp. 1-275 In: The Biology of Lampreys, vol. 1 (M. W. Hardisty, and I. C. Potter, Eds.). London: Academic Press (1971a).

Hardisty, M. W., and I. C. Potter. The behaviour, ecology and growth of larval lampreys. In: The Biology of Lampreys, vol. 1 (M. W. Hardisty, and I. C. Potter, Eds.). London: Academic Press (1971b).

Harvey, J., and I. Cowx. Monitoring the River, Brook and Sea Lamprey, Lampetra fluviatilis, L. planeri and Petromyzon marinus. In: Conserving Natura 2000 Rivers Monitoring Series No. 5, Peterborough: English Nature (2003).

Heinrich, J. W., K. M. Mullett, M. J. Hansen, J. V. Adams, G. T. Klar, D. A. Johnson, G. C. Christie, and R. J. Young. Sea lamprey abundance and management in Lake Superior, 1957 to 1999. J. Great Lakes Res., 29: 566-583 (2003).

HELCOM. HELCOM Red list of threatened and declining species of lampreys and fish of the Baltic Sea. Baltic Sea Environ. Proc., 109: 1-40 (2006).

Hogg, R., S. M. Coghlan, and J. Zydlewski. Anadromous sea lampreys recolonize a Maine coastal river tributary after dam removal. Trans. Am. Fish Soc., 142: 1381-1394 (2013).

Hogg, R. S., S. M. Coghlan, J. Zydlewski, and K. S. Simon. Anadromous sea lampreys (Petromyzon marinus) are ecosystem engineers in a spawning tributary. Freshwater Biol., 59: 1294-1307 (2014).

Holcik, J. Freshwater fishes of Europe (Vol I part II), p. 469 In: General Introduction to Fishes and Acipenseriformes. Aula Verlag: Wiesbaden (1989).

Holčì, J., A. Delić, M. Kučinić, V. Bukvić, and M. Vater. Distribution and morphology of the sea lamprey from the Balkan coast of the Adriatic Sea. J. Fish Biol., 64: 514-527 (2004).

Hunn, J. B., and W. D. Youngs. Role of physical barriers in the control of sea lamprey (Petromyzon marinus). Can. J. Fish. Aquat. Sci., 37: 2118-2122 (1980).

ICES. Report of the study group on the status of diadromous fish species (SGSDFS), ICES CM 2005/I:02 (2005).

Igoe, F., D. T. G. Quigley, F. Marnell, E. Meskell, W. Óconnor, and C. Byrne. The sea lamprey Petromyzon marinus (L.), river lamprey Lampetra fluviatilis (L.) and brook lamprey Lampetra planeri (Bloch) in Ireland: general biology, ecology, distribution and status with recommendations for conservation. Biol. Environ., 104B: 43-56 (2004).

Iliashenko, V. Y., and E. I. Iliashenko. p. 143. Krasnaya Kniga Rossii: Pravovye akty (Red Data Book of Russia: legislative acts). Moscow: State committee of the Russian Federation for Environmental Protection (2000).

Imre, I., and G. E. Brown. Behavioural response of larval sea lamprey (Petromyzon marinus) in a laboratory environment to potential damage-released chemical alarm cues. Can. J. Zool., 92: 443-447 (2014).

Imre, I., G. E. Brown, R. A. Bergstedt, and R. McDonald. Use of chemosensory cues as repellents for sea lamprey: potential directions for population management. J. Great Lakes Res., 36: 790-793 (2010).

Imre, I., R. T. Di Rocco, C. F. Belanger, G. E. Brown, and N. S. Johnson. The behavioural response of adult Petromyzon
1140 
marinus to damage released alarm and predator cues. J. Fish Biol., 84: 1490-1502 (2014).

Johnson, N. S., T. J. Buchinger, and W. Li. Reproductive Ecology of Lampreys, pp. 265-296. In: Lampreys: Biology, Conservation and Control, Vol. 1 (M. F. Docker, Eds.). 1205 Dordrecht: Fish and Fisheries Series, 37. Springer Science + Business Media BV (2015).

Johnson, N. S., M. A. Luehring, M. J. Siefkes, and W. Li. Mating pheromone reception and induced behavior in ovulating female sea lampreys. N. Am. J. Fish Manage., 26: 88-96

$1210 \quad$ (2006).

Johnson, N. S., M. J. Siefkes, and W. Li. Capture of ovulating female sea lampreys in traps baited with spermiating male sea lampreys. N. Am. J. Fish Manage., 25: 67-72 (2005).

Johnson, N. S., M. J. Siefkes, C. M. Wagner, G. Bravener, T.

1215 Steeves, M. Twohey, and W. Li. Factors influencing capture of invasive sea lamprey in traps baited with a synthesized sex pheromone component. J. Chem. Ecol., 41: 913-923 (2015).

Johnson, N. S., M. J. Siefkes, C. M. Wagner, H. Dawson, H.

1220 Wang, T. Steeves, and W. Li. A synthesized mating pheromone component increases adult sea lamprey (Petromyzon marinus) trap capture in management scenarios. Can. J. Fish Aquat. Sci., 70: 1101-1108 (2013).

Johnson, N. S., S. S. Yun, H. T. Thompson, C. O. Brant, and W.

1225 Li. A synthesized pheromone induces upstream movement in female sea lamprey and summons them into traps. Proc. Natl. Acad. Sci., 106: 1021-1026 (2009).

Joint Nature Conservation Committee. Second Report by the UK under Article 17 on the implementation of the Habi-

1230 tatsb Directive from January 2001 to December 2006. Peterborough: JNCC. Available from: www.jncc.gov.uk/article17 (2007).

Jones, M. L. Toward improved assessment of sea lamprey population dynamics in support of cost-effective sea lamprey management. J. Great Lakes Res., 33: 35-47(2007).

Jonsson, B., and N. Jonsson. A review of the likely effects of climate change on anadromous Atlantic salmon Salmo salar and brown trout Salmo trutta, with particular reference to water temperature and flow. J. Fish Biol., 75: 2381-2447 (2009).

Kålås, J. A., Å. Viken, S. Henriksen, and S. Skjelseth. The 2010 Norwegian Red List for Species. Trondheim: Norwegian Biodiversity Information Centre (2010).

Keefer, M. L., C. C. Caudill, T. S. Clabough, M. A. Jepson, E. L.

1245 Johnson, C. A. Peery, M. D. Higgs, and M. L. Moser. Fishway passage bottleneck identification and prioritization: A case study of Pacific lamprey at Bonneville Dam. Can. J. Fish Aquat. Sci., 70: 1551-1565 (2013).

Kelly, F. L., and J. J. King. A review of the ecology and distribu-

1250 tion of three lamprey species, Lampetra fluviatilis (L.), Lampetra Planeri (Bloch) and Petromyzon marinus (L.): A context for conservation and biodiversity considerations in Ireland. Biol. Environ., 101B: 165-185 (2001).

Kemp, P. S., I. J. Russon, A. S. Vowles, and M. C. Lucas. The 1255 influence of discharge and temperature on the ability of upstream migrant adult river lamprey (Lampetra fluviatilis) to pass experimental overshot and undershot weirs. River Res. Appl., 27: 488-498 (2011).

Klamath River Expert Panel. Scientific assessment of two

1260 dam removal alternatives on lamprey, final report. http://northamerica.atkinsglobal.com/ /media/Files/A/
Atkins-North-America/Attachments/klamath-river/Lamp rey\%20Final\%20EP\%20Report\%201-14-11.pdf. Accessed 20 Dec 2013 (2010).

Klar, G. T., and R. J. Young. Integrated management of sea lampreys in the Great Lakes, 2002. U.S. Fish and Wildlife Service and Department of Fisheries and Oceans Canada, Annual Report to the Great Lakes Fishery Commission, Marquette, Michigan (2002).

Kuratani, S. Evolution of the vertebrate jaw from developmental perspectives. Evol. Dev., 14: 76-92 (2012).

Kusakabe, R., and S. Kuratani. Evolution and developmental patterning of the vertebrate skeletal muscles: Perspectives from the lamprey. Dev. Dynam., 234: 824-834 (2005).

Lamb, T. D., S. P. Collin, and E. N. Pugh. Evolution of the vertebrate eye: opsins, photoreceptors, retina and eye cup. Nat. Rev. Neurosci., 8: 960-976 (2007).

Lark, J. G. I. An early record of the sea lamprey (Petromyzon marinus) from Lake Ontario. J. Fish Res. Board. Can., 30: 131-133 (1973).

Larson, G. L., G. C. Christie, D. A. Johnson, J. F. Koonce, K. M. Mullett, and W. P. Sullivan. The history of sea lamprey control in Lake Ontario and updated estimates of suppression targets. J. Great Lakes Res., 29: 637-654 (2003).

Lasne, E., M. R. Sabatié, N. Jeannot, and J. Cucherousset. The effects of dam removal on river colonization by sea lamprey Petromyzon Marinus. River Res. Appl., 31: 904-911 (2015).

Lasne, E., M. R. Sabatié, J. Tremblay, L. Beaulaton, and J. M. Roussel. A new sampling technique for larval lamprey population assessment in small river catchments. Fish Res., 106: 22-26 (2010).

Lassalle, G., M. Béguer, L. Beaulaton, and E. Rochard. Diadromous fish conservation plans need to consider global warming issues: An approach using biogeographical models. Biol. Conserv., 141: 1105-1118 (2008).

Lassalle, G., and E. Rochard. Impact of twenty-first century climate change on diadromous fish spread over Europe, North Africa and the Middle East. Glob. Change Biol., 15: 10721089 (2009).

Lavis, D. S., A. Hallett, E. M. Koon, and T. C. McAuley. History of and advances in barriers as an alternative method to suppress sea lampreys in the Great Lakes. J. Great. Lakes Res., 29: 362-372 (2003).

Li, W., M. J. Siefkes, A. P. Scott, and J. H. Teeter. Sex pheromone communication in the sea lamprey: implications for integrated management. J. Great Lakes Res., 29: 85-94 (2003).

Li, W., M. Twohey, M. Jones, and M. Wagner. Research to guide use of pheromones to control sea lamprey. J. Great Lakes Res., 33: 70-86 (2007).

Lucas, M. C., D. H. Bubb, M. H. Jang, K. Ha, and J. E. G. Masters. Availability of and access to critical habitats in regulated rivers: effects of low-head barriers on threatened lampreys. Freshwater Biol., 54: 621-634 (2009).

Lusk, S., L. Hanel, and V. Lusková. Red list of the ichthyofauna of the Czech Republic: development and present status. Folia Zool., 53: 215-226 (2004).

MacEachen, D. C., R. W. Russell, and D. M. Whittle. Spatial distribution of mercury and organochlorine contaminants in Great Lakes sea lamprey (Petromyzon marinus). J. Great Lakes Res., 26: 112-119 (2000).

Madenjian, C. P., B. D. Chipman, and J. E. Marsden. New estimates of lethality of sea lamprey (Petromyzon marinus) 
attacks on lake trout (Salvelinus namaycush): Implications for fisheries management. Can. J. Fish Aquat. Sci. 65: 535542 (2008).

Maitland, P. S. Review of the ecology of lampreys in northern Europe. Can. J. Fish Aquat. Sci., 37: 1944-1952 (1980).

Maitland, P. S. In: Ecology of the River, Brook and Sea Lamprey

1330 Conserving Natura 2000 Rivers Ecology Series No. 5. Peterborough: English Nature (2003).

Maitland, P. S. Ireland's most threatened and rare freshwater fish: An international perspective on fish conservation. Biol. Environ., 104B: 5-16 (2004).

1335 Maitland, P. S., C. B. Renaud, B. R. Quintella, D. A. Close, and M. F. Docker. Conservation of Native Lampreys, pp. 376403. In Lampreys: Biology, Conservation and Control, Vol. 1 (M. F. Docker, Eds.). Dordrecht: Fish and Fisheries Series, 37. Springer Science + Business Media BV (2015).

1340 Malmqvist, B. Population structure and biometry of Lampetra planeri (Bloch) from three different watersheds in South Sweden. Arch. Hydrobiol., 84: 65-86 (1978).

Malmqvist, B. The spawning migration of the brook lamprey, L. planeri Bloch, in a South Swedish stream. J. Fish Bio., 16:

1345 105-114 (1980a).

Malmqvist, B. Habitat selection of larval brook lampreys ( $L$. planeri, Bloch) in a South Swedish stream. Oecologia, 45: 33-38 (1980b).

Masters, J. E. G., M.-H. Jang, K. Ha, P. D. Bird, P. A. Frear, and

1350 M. C. Lucas. The commercial exploitation of a protected anadromous species, the river lamprey (Lampetra fluviatilis (L.)), in the tidal River Ouse, north-east England. Aquat. Conserv., 16: 77-92 (2006).

Mateus, C. S., R. Rodríguez-Muñoz, B. R. Quintella, M. J.

1355 Alves, and P. R. Almeida. Lampreys of the Iberian Peninsula: distribution, population status and conservation. Endanger. Species Res., 16: 183-198 (2012).

McLaughlin, R. L., A. Hallett, T. C. Pratt, L. M. O’Connor, and D. G. McDonald. Research to guide use of barriers, traps,

1360 and fishways to control sea lamprey. J. Great Lakes Res., 33: 7-19 (2007).

McLean, A. Understanding behaviour to improve trapping success of invasive sea lamprey. Master Dissertation. University of Guelph. Ontario, Canada, pp. 2-21 (2014).

1365 Meckley, T. D., C. M. Wagner, and E. Gurarie. Coastal movements of migrating sea lamprey (Petromyzon marinus) in response to a partial pheromone added to river water: implications for management of invasive populations. Can. J. Fish Aquat. Sci., 71: 533-544 (2014).

1370 Mills, E. L., J. M. Casselman, R. Dermott, J. D. Fitzsimons, G. Gal, K. T. Holeck, and T. J. Stewart. Lake Ontario: food web dynamics in a changing ecosystem (1970-2000). Can. J. Fish Aquat. Sci., 60: 471-490 (2003).

Morrongiello, J. R., D. A. Crook, A. J. King, D. S. Ramsey, and

1375 P. Brown. Impacts of drought and predicted effects of climate change on fish growth in temperate Australian lakes. Glob. Change Biol., 17: 745-755 (2011).

Morse, T. J., M. P. Ebener, E. M. Koon, S. B. Morkert, D. A. Johnson, D. W. Cuddy, J. W. Weisser, K. M. Mullet, and J.

1380 H. Genovese. A case history of sea lamprey control in Lake Huron: 1979 to 1999. J. Great Lakes Res., 29: 599-614 (2003).

Moursund, R. A., D. D. Dauble, and M. Langeslay. Turbine intake diversion screens: investigating effects on Pacific
Moyle, P. B., L. R. Brown, S. D. Chase, and R. M. Quiñones. Status and conservation of lampreys in California, pp. 279292. In: Biology, Management, and Conservation of Lampreys in North America (Brown, L.R, S. D. Chase, M. G. Mesa, R. J. Beamish, and P. B. Moyle, Eds.). American Fisheries Society, Symposium 72, Bethesda (2009).

Mullett, K. M., J. W. Heinrich, J. V. Adams, R. J. Young, M. P. Henson, R. B. McDonald, and M. F. Fodale. Estimating lake-wide abundance of spawning phase sea lampreys (Petromyzon marinus) in the Great Lakes: extrapolating from sampled streams using regression models. J. Great Lakes. Res., 29: 240-252 (2003).

NatureServe. Petromyzon marinus. The IUCN Red List of Threatened Species. Version 2014.3. Accessed on 09 February 2015 (2013).

Nikitina, N., M. Bronner-Fraser, and T. Sauka-Spengler. The sea lamprey Petromyzon marinus: a model for evolutionary and developmental biology. Cold Spring Harbor Protocols doi:10.1101/pdb.emo113 (2009).

Nislow, K. H., and B. E. Kynard. The role of anadromous sea lamprey in nutrient and material transport between marine and freshwater environments. Am. Fish Soc. Symp., 69: 485-494 (2009).

Nunn, A. D., and I. G. Cowx. Restoring river connectivity: prioritizing passage improvements for diadromous fishes and lampreys. Ambio, 41: 402-409 (2012).

Oliveira, J. M., M. T. Ferreira, A. N. Pinheiro, and J. H. Bochechas. A simple method for assessing minimum flows in regulated rivers: The case of sea lamprey reproduction. Aquat. Conserv., 14: 481-489 (2004).

OSPAR Commission. Background document for Sea lamprey Petromyzon marinus. Biodiversity Series. London: OSPAR Commission (2009).

Pedro, S., I. Caçador, B. R. Quintella, M. J. Lança, and P. R. Almeida. Trace element accumulation in anadromous sea lamprey spawners. Eco.l Freshw. Fish., 23: 193-207 (2014).

Pinder, A. C., E. Hopkins, L. J. Scott, and J. R, Britton. Rapid visual assessment of spawning activity and associated habitat utilisation of sea lamprey (Petromyzon marinus Linnaeus, 1758) in a chalk stream: implications for conservation monitoring. J. Appl. Ichthyol., doi: 10.1111/ jai.13010. (2015).

Potter, I. C. Ecology of larval metamorphosing lampreys. Can. J. Fish Aquat. Sci., 37: 1641-57 (1980).

Povž, M. Distribution and conservation status of the lampreys in Slovenia. Bull Lampetra VII: 84-91 (2011).

Quintella, B. R., N. O. Andrade, and P. R. Almeida. Distribution, larval stage duration and growth of the sea lamprey ammocoetes, Petromyzon marinus L., in a highly modified river basin. Ecol. Freshw. Fish., 12: 286-293 (2003).

Renaud, C. B. Conservation status of Northern Hemisphere lampreys (Petromyzontidae). J. App. Ichthyol., 13: 143-148 (1997).

Renaud, C. B. Lampreys of the world. An annotated and illustrated catalogue of lamprey species known to date, pp. 109210. In: FAO Species Catalogue for Fishery Purposes. No. 5. Rome: FAO (2011).

Renaud, C. B., K. L. E. Kaiser, and M. E. Comba. Historical versus recent levels of organochlorinen contaminants in lamprey larvae of the St. Lawrence River basin, Québec. Can. J. Fish Aquat. Sci., 52: 268-275 (1995). 
Repečka, R. The species composition of the ichthyofauna in the Lithuanian economic zone of the Baltic Sea and the Curonian Lagoon and its changes in recent years. Acta. Zool. Litu., 13: 149-157 (2003).

Russon, I. J., P. S. Kemp, and M. C. Lucas. Gauging weirs impede the upstream migration of adult river lamprey Lampetra fluviatilis. Fish. Manage. Ecol., 18: 201-210 (2011).

1455 Saat, T., R. Järvekülg, and R. Eschbaum. The status of threatened freshwater fish species in Estonia. Int Symp Freshwater Fish Conserv: Options for the Future. 30 Oct-5 Nov 2000, Albufeira, Portugal, pp 24 (2000).

Sawyer, A. J. Prospects for integrated pest management of the

1460 sea lamprey (Petromyzon marinus). Can. J. Fish Aquat. Sci., 37: 2081-2092 (1980).

Schröder, V., and C. Garcia de Leaniz. Discrimination between farmed and free-living invasive salmonids in Chilean Patagonia using stable isotope analysis. Biol. Invasions, 13: 203-

$1465213(2011)$.

Shirakawa, H., S. Yanai, and A. Goto. Lamprey larvae as ecosystem engineers: physical and geochemical impact on the streambed by their burrowing behaviour. Hydrobiologia, 701: 313-322 (2013).

1470 Silva, S., M. J. Servia, R. Vieira-Lanero, S. Barca, and F. Cobo. Life cycle of the sea lamprey Petromyzon marinus: duration of and growth in the marine life stage. Aqut. Biol., 18: 5962 (2013).

Smith, B. R., and J. J. Tibbles. Sea lamprey (Petromyzon mari-

$1475 n u s)$ in Lakes Huron, Michigan, and Superior: history of invasion and control, 1936-78. Can. J. Fish Aquat. Sci., 37: 1780-1801 (1980).

Smith, J. J., S. Kuraku, C. Holt, T. Saukaâ€“Spengler, et al. Sequencing of the sea lamprey (Petromyzon marinus)

1480 genome provides insights into vertebrate evolution. Nat. Genet., 45: 415-421 (2013).

Sorensen, P. W., and T. R. Hoye. A critical review of the discovery and application of a migratory pheromone in an invasive fish, the sea lamprey Petromyzon marinus L. J. Fish

1485 Biol., 71: 100-114 (2007).

Sorensen, P. W., and L. A. Vrieze. The chemical ecology and potential application of the sea lamprey migratory pheromone. J. Great Lakes Res., 29: 66-84 (2003).

Sousa, R., M. Araújo, and C. Antunes. Habitat modifications by 1490 sea lampreys ( Petromyzon marinus) during the spawning season: effects on sediments. J. App. Ichthyol., 28: 766-771 (2012).

Suíssas, C. Assessing the feasibility of commercial exploitation of sea lamprey (Petromyzon marinus) in Minho and Tagus river basins. Master's Thesis, University of Évora, Évora, pp 1495 21-38 (2010).

Taverny, C., G. Lassalle, I. Ortusi, C. Roqueplo, M. Lepage, and P. Lambert. From shallow to deep waters: Habitats used by larval lampreys (genus Petromyzon and Lampetra) over a western European basin. Ecol. Freshw. Fish, 21: 87-99 (2012).

Teeter, J. Pheromone communication in sea lampreys (Petromyzon marinus): Implications for population management. Can. J. Fish Aquat. Sci., 37: 2123-2132 (1980).

Thiel, R., H. M. Winkler, and R. Neumann. Erfassung von FFH-Anhang II-Fischarten in der deutschen AWZ von Nord-und Ostsee. Final report for the German Federal Agency of Nature Conservation, available at www.bfn. de/habitatmare/de/downloads/berichte/Erfassung_FFH_ Fischarten_Nordsee-Ostsee_2007.pdf (2007).

Thiel, R., H. M. Winkler, R. Neumann, T. Gröhsler, U. Böttcher, S. Spratte, and U. Hartmann. Endangered anadromous lampreys in the southern Baltic Sea: spatial distribution, long-term trend, population status. Endanger Species Res., 8: 233-247 (2009).

Tuunainee, P., E. Ikonen, and H. Auvinen. Lampreys and lamprey fisheries in Finland. Can. J. Fish Aquat. Sci., 37: 19531959 (1980).

Twohey, M. B., J. W. Heinrich, J. G. Seelye, K. T. Fredricks, R. A. Bergstedt, C. A. Kaye, and G. C. Christie. The sterilemale-release technique in Great Lakes sea lamprey management. J. Great Lakes Res., 29: 410-423 (2003b).

Twohey, M. B., P. W. Sorensen, and W. Li. Possible applications of pheromones in an integrated sea lamprey management program. J. Great Lakes Res., 29: 794-800 (2003a).

Wagner, C. M., M. L. Jones, M. B. Twohey, and P. W. Sorensen. A field test verifies that pheromones can be useful for sea lamprey (Petromyzon marinus) control in the Great Lakes. Can. J. Fish Aquat. Sci., 63: 475-479 (2006).

Wagner, C. M., E. M. Stroud, and T. D. Meckley. A deathly odor suggests a new sustainable tool for controlling a costly invasive species. Can. J. Fish Aquat. Sci., 68: 1157-1160 (2011).

Walaszczyk, E. J., N. S. Johnson, J. P. Steibel, and W. Li. Effects of sex pheromones and sexual maturation on locomotor activity in female sea lamprey (Petromyzon marinus). J. Biol. Rhythm., 28: 218-226 (2013).

Yun, S. S., A. P. Scott, and W. Li. Pheromones of the male sea lamprey, Petromyzon marinus L.: structural studies on a new compound, 3-keto allocholic acid, and 3-keto petromyzonol sulfate. Steroids. 68: 297-304 (2003). 